\title{
Digital Teaching: In Search Of An Effective Paperless Platform For Classroom Activities
}

Flory Anette Dieck-Assad, Tecnológico de Monterrey, Mexico

\begin{abstract}
Sydney J. Harris advises us, "The whole purpose of education is to turn mirrors into windows". Never like today, are we in the need to help teachers and professors to guide their students to open windows and get involved with the geopolitical and economic needs of the world. This paper tests the hypothesis that Microsoft OneNote Class Notebook (MONCN), used in undergraduate Finance courses as a tool for digital teaching, can both promote sustainable development and make the students become leaders, using this innovative tool of learning as part of their own activities and lives in the future. The test of the hypothesis also demonstrates that students manage to make the classroom time more effective and efficient for learning when using MONCN as a paperless technological platform. Thus, without impacting the effectiveness and quality of education, MONCN surges as a tool for inspiring the students to become committed citizens that can change the world and collaborate in the fight of climate change.
\end{abstract}

Keywords: Microsoft OneNote Class Notebook; Paperless; Education; Sustainable Development; Digital Teaching

\section{INTRODUCTION}

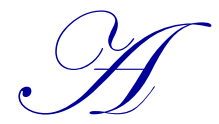

t any level of education, teachers and professors need to find the best academic strategy to support an educational process that could both promote a sustainable future for the world and at the same time provide an effective digital teaching experience. How could professors motivate their students to feel part of the change towards sustainable development without decreasing the excellence of teaching in the process? The objective of this paper is to present Microsoft OneNote Class Notebook (MONCN) as an effective paperless technological platform for activity submissions at the university level (OneNote, 2018).

This paper tests the hypothesis that MONCN, used in undergraduate Finance courses at Tecnologico de Monterrey, in Mexico, as a tool for digital teaching, can both promote sustainable development and make the students become leaders of their own learning process, by using this innovative tool of learning as part of their own activities and lives in the future. The test of the hypothesis also demonstrates that students manage to make the classroom time more effective and efficient for learning when using MONCN as a paperless technological platform. Thus, without impacting the effectiveness and quality of education, MONCN surges as a tool for inspiring the students to become committed citizens that can change the world and collaborate in the fight of climate change.

The teaching target is to make the students realize that increasing their expertise in a paperless technological platform will help them be more valuable for a company in the future because they will present another useful ability compared with other candidates for the same job, as well as feeling themselves as citizens of the world collaborating with the defense of the planet when learning in a paperless environment (OneNote Team, 2014a). Being ethical citizens of the world, they could become key elements to trigger an exponential awareness of an increased citizen participation in favor of our planet.

The objective of this paper is to show the results of the tested hypothesis with undergraduate Finance students at Tecnologico de Monterrey in the state of Nuevo Leon, Mexico, during 2017 when using MONCN as a paperless teaching platform. The emphasis will be in testing how the students become sensitive citizens of the world, concerned with the global warming dilemma of the century, among others.

The explanation of MONCN that is required to understand this paperless technological platform is widely explained by Dieck-Assad (2018). The only purpose of this paper is to show, through the tested hypothesis, that teaching practices using a technological paperless platform could inspire professors to become life examples of their 
commitment in the fight for sustainable development and inspire their students the love for the planet at the same time, without decreasing the quality of education.

This paper is composed by the following four sections: literature review; the methodology used to test the hypothesis in undergraduate Finance courses at Tecnologico de Monterrey, Mexico; the analysis of the results, and the section of conclusions and recommendations.

\section{LITERATURE REVIEW}

The consequences of humans' daily tasks have affected the stability of the Earth's resources, triggering people and companies to devout their research efforts towards creating a healthy and favorable environment. Researchers strive to procure a foreseeable future where today's actions that contribute to the planet's welfare can be greatly appreciated by future generations.

According to Greenpeace (2018), forests are being depleted around the world, along with all species that live within them. Mexico is the $5^{\text {th }}$ country with the highest deforestation rate in the planet: according to the Geography Institute at the Universidad Nacional Autonoma de Mexico (UNAM), Mexico loses 500,000 hectares of forests and jungles each year (Couturier \& Mas, 2009). This endangers the life of a great variety of plants and animals, as well as numerous communities which have depended on this ecosystem as a form of subsistence throughout generations. Deforestation has motivated companies to offer valuable proposals within their own field of action to alleviate this problem. MONCN arises as an innovative paperless technological teaching tool (OneNote Team, 2014b).

How is the use of technology in teaching evolving? According to Once Noticias (2013), in these modern times preschool students draw and color using digital tablets; they abandoned the use of paper and crayons, converting preschool classes into technology-adopting paperless classrooms. These changes mark the standards by which the new modern lifestyle for children becomes a challenge for innovation in undergraduate teaching which also triggers the academic improvement of professors in their teaching process.

Furthermore, in 2013 young students from Ecuador expressed their concern for fostering a sustainable environment and love for the planet in their daily activities. NTN24.com (2013) presents the information about the legal initiative these young people proposed to the Ecuadorian government to try to avoid newspaper printing in order to contribute to reduce deforestation. The President of Ecuador, Rafael Correa, answered this initiative by ordering newspapers to only publish digital media and avoid the printing of tons of paper.

Nowadays, academic innovation seeks better teaching practices through an ecologic and sustainable awareness. This paper aims to be a continuation of research in these matters (Dieck-Assad, 2018), by testing another hypothesis that could consolidate MONCN as an effective teaching tool for inspiring the students to become committed citizens that can change the world and collaborate in the fight of climate change.

\section{HYPOTHESIS DEFINITION AND METHODOLOGY}

\section{Definition of the Hypothesis}

The tested hypothesis is defined as follows: MONCN, used as a digital teaching tool in undergraduate Finance courses, is an effective paperless technological teaching platform which can both promote sustainable development and make the students become committed citizens that can change the world and collaborate in the fight of climate change and at the same time, becoming leaders of their own process of learning without decreasing the quality of their education. This hypothesis was tested with the results of a written survey applied to the students at the end of the financial courses.

\section{Methodology}

Eight undergraduate Finance courses were tested during 2017. MONCN was used as a paperless teaching platform in 4 courses and the traditional teaching approach in the other 4 courses. The same survey was applied to the 8 Finance courses asking the students if the course promoted, besides financial knowledge, a strengthening of their approach towards ethics and sustainable development, becoming committed citizens of the world in the fight of climate change. The survey was aimed to identify the strength of MONCN as a paperless learning platform that could become an 
effective tool to promote values and increase environmental concern, without damaging the transference of knowledge.

Since there is no numerical evaluation of the effectiveness of the hypothesis, the questions were transformed into quantitative results. Additionally, the survey included an open question to let the student express his/her personal point of view in order to provide qualitative results for the proposed hypothesis.

The hypothesis was tested during 2017 considering 4 courses each semester: January-May 2017 and August-December 2017. The purpose was to have as many observations as possible to increase the reliability of the results. Two courses of "Financial Institutions" were taught by the same professor in the exact same conditions, covering the exact same material. The other two courses of "International Finance" were taught by the same professor in the exact same conditions, covering the exact same material. Thus, for the experiment, one course of each subject was chosen to be the Traditional Group where the strategy of teaching was the traditional one with physical handing of classroom activities (homework, problem solving laboratories, article analysis, etc.); The other group was called the Pilot Group in which everything was handed in digital formats (paperless style) using the MONCN paperless digital platform. The summary is as follows:

\section{Semester of January-May 2017:}

Course A: Financial Institutions taught in Spanish as the Traditional Group: 30 students

Course B: Financial Institutions taught in Spanish as the Pilot Group: 30 students

Course C: International Finance taught in English as the Traditional Group: 9 students

Course D: International Finance taught in English as the Pilot Group: 12 students

\section{Semester of August-December 2017:}

Course E: Financial Institutions taught in Spanish as the Traditional Group: 22 students

Course F: Financial Institutions taught in Spanish as the Pilot Group: 23 students

Course G: International Finance taught in English as the Traditional Group: 27 students

Course H: International Finance taught in English as the Pilot Group: 23 students

The quantity of the students surveyed in 2017 was a total of 176 students as follows:

1. Traditional Group: 88 surveyed students.

2. Pilot Group: 88 surveyed students.

\section{Analysis of the Numerical Results}

Before notifying the students about their final grades, in order to decrease any external influence in the results, the survey was applied exactly the same day for both the Traditional and the Pilot groups, totaling 4 courses in JanuaryMay 2017 and 4 courses in August-December 2017. The results suggest that from the students' statistical and qualitative points of view, the proposed hypothesis cannot be rejected. The Pilot group had more burden in the load of activities at the beginning of the course because the students had to learn how to use MONCN as a paperless technological platform. However, at the end, they felt relieved of the physical handing of activities; they felt happy to send homework and other activities in a 24/7 scheme, at anytime from anywhere. This was so, that even the students felt not only happier but they felt an improvement in their education. They also expressed that the team work activities resulted easier and were happy to be involved in debates through the platform. The results are a valuable input for professors who want happier and better students eager to continue their daily learning. Furthermore, students who are part of the Student Confederation at Campus, proposed the use of MONCN for the campus activities of the student association, resulting in a better team work and a better organization of their tasks. The blessings of disruptive technologies in education came true with these results, because it can be said that this new paperless technological platform replaced a traditional student mind with an open student mind that can envision new possibilities for their daily life. The trend of the results were the same for both periods during the year; thus, it was decided best to present the numerical results for the whole year according to the division of Traditional vs. Pilot groups. 
In order to profile the students, the survey was replicated as it was done in Dieck-Assad (2018), to be sure that the student sample was not biased. Table 1 presents the results of the general questions of the survey that arrived to a similar trend as the one presented by Dieck-Assad (2018), concluding that the majority of the students had not used MONCN before; thus, it is an accepted sample for testing the hypothesis.

Table 1. Global Results from the Survey - January 2017 - December 2017

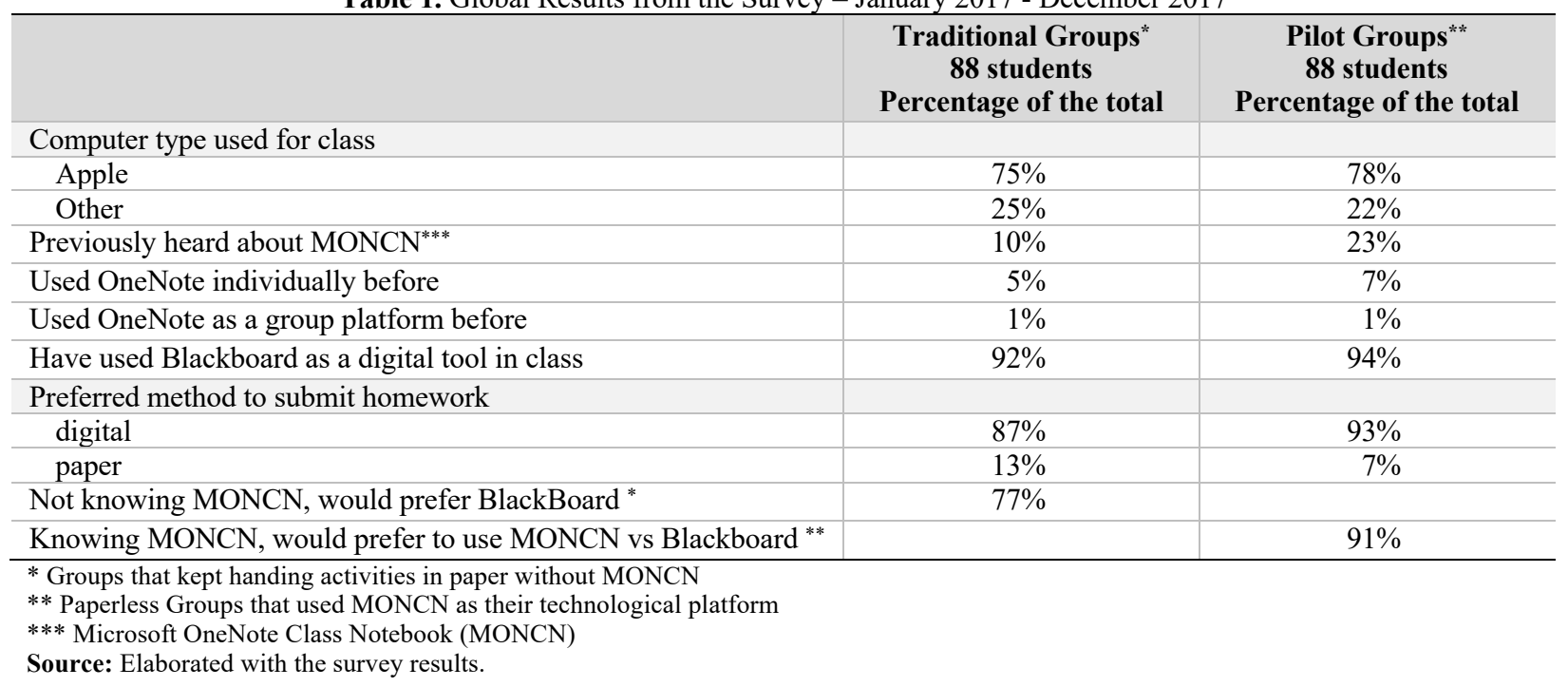

From the statistical results shown in Table 1, it is possible to conclude:

1. The sample is not biased because between $75 \%$ and $78 \%$ of the surveyed students in both samples are used to Apple-brand computers, thus, showing equivalent equipment for doing their work. Thus, it is an homogeneous sample.

2. Only between $10 \%$ and $23 \%$ of the samples had heard about MONCN before. Thus, the majority did not know about this technological platform making it possible to evaluate their reactions to a technology that was really new for them, and it was possible to evaluate their averse or compliant attitude towards change.

3. Only between $5 \%$ and $7 \%$ of the students have used individually the OneNote application before.

4. Only $1 \%$ of the students have used the OneNote application as a group platform before.

5. As it was expected, because Tecnologico de Monterrey offers Blackboard as a learning platform in all its campuses, it was logical to learn that between $92 \%$ and $94 \%$ of the students are used to this digital tool for task submissions in class.

6. It is important to point out that professors at Tecnologico de Monterrey tend to receive homework in paper vs digital. This is because of a limitation of the Blackboard platform which only accepts digital submissions as attachments. Revision of submitted homework becomes a high time consuming activity because professors must open each attachment first in order to be able to evaluate them. The professor must also enable a special space in blackboard where the student could submit his/her homework. So, considering that the majority of the students between $87 \%$ and $93 \%$ are fond of digital submissions, with MONCN this process is improved because this digital platform lets the student upload the homework as a picture instead of an attachment, making its revision easier.

7. Once the student learns how to use MONCN, $91 \%$ of the students prefer this platform instead of Blackboard. However, in the courses that did not have contact with MONCN, 77\% still prefer the official university platform of Blackboard.

The Pilot Group answered another specific survey in order to evaluate their experience using MONCN. The purpose was to identify pros and cons of this paperless digital platform from the students' point of view. Table 2 summarizes the results of 88 surveys applied to the Pilot Group using the Likert scale from 1 to 5 . In order to verify that the student 
was not biased, there were positive statements and negative statements about MONCN, where the students decide if they Totally Agree with a number 5 or Totally Disagree with number 1.

Table 2. Pros and Cons of using Microsoft OneNote Class Notebook (MONCN) - January - December 2017 According to the Students (survey), Numerical results for the Pilot Group

\begin{tabular}{|c|c|c|c|}
\hline CONCEPT & $\begin{array}{c}\text { Average } \\
\text { Result on a } \\
\text { scale of } 1 \text { to } 5\end{array}$ & $\begin{array}{l}\text { Standard } \\
\text { Deviation* }\end{array}$ & $\begin{array}{c}\text { Independent } \\
\text { t-test* }\end{array}$ \\
\hline $\begin{array}{l}\text { Using MONCN made me realize the importance of the concept of } \\
\text { sustainable development }\end{array}$ & 4.25 & 0.6989 & 3.355417 \\
\hline $\begin{array}{l}\text { MONCN helped me envision how a disruptive technology can improve } \\
\text { my education and my life }\end{array}$ & 4.55 & 0.6765 & 6.302859 \\
\hline MONCN made me feel leader of my own educational process & 4.53 & 0.6423 & 6.804068 \\
\hline MONCN increased my desire to become a committed citizen & 4.41 & 0.7525 & 5.099381 \\
\hline MONCN decreased the burden to carry paper in my backpack & 4.90 & 0.3403 & 2.818645 \\
\hline MONCN made me save in educational materials: paper, pens, pencils, etc. & 4.77 & 0.5617 & 3.795257 \\
\hline $\begin{array}{l}\text { MONCN made me understand how I can help as a student to join the war } \\
\text { against climate change }\end{array}$ & 4.91 & 0.2891 & 2.949576 \\
\hline MONCN helped me increased the quality of my education & 4.88 & 0.4237 & 2.766948 \\
\hline MONCN made me feel a free educational environment & 4.80 & 0.5705 & 3.363242 \\
\hline $\begin{array}{l}\text { MONCN made me be feel connected with my classmates and my team } \\
24 / 7 \text { making my team work easier }\end{array}$ & 4.36 & 0.8601 & 3.965957 \\
\hline MONCN was the bridge to connect my activities with class discussion & 4.92 & 0.2721 & 2.741992 \\
\hline $\begin{array}{l}\text { MONCN made my student life happier, helping organize my student life } \\
\text { better }\end{array}$ & 4.86 & 0.4336 & 2.949576 \\
\hline MONCN inspired me about the good things I can do with technology & 4.94 & 0.2328 & 2.289315 \\
\hline MONCN is a difficult tool to use & 1.75 & 0.8339 & 2.812311 \\
\hline $\begin{array}{l}\text { MONCN made me have an unbearable burden in class making my student } \\
\text { life harder }\end{array}$ & 1.77 & 0.9794 & 2.176824 \\
\hline $\begin{array}{l}\text { MONCN did not strengthen my identity as responsible citizen of the } \\
\text { world }\end{array}$ & 1.72 & 1.0388 & 2.565256 \\
\hline MONCN is an undesired additional task in the course & 1.32 & 0.7957 & 3.750907 \\
\hline MONCN was difficult to understand & 1.41 & 0.7970 & 4.814657 \\
\hline MONCN made it difficult to submit activities, homework and notes & 1.13 & 0.5427 & 2.160623 \\
\hline $\begin{array}{l}\text { After knowing MONCN I would rather go back to the traditional } \\
\text { approach of my education in future courses }\end{array}$ & 1.05 & 0.2094 & 2.035401 \\
\hline
\end{tabular}

According to the statistical tests, all the answers are significant at $\mathrm{p} \leq 0.05$ with a $95 \%$ confidence interval. Thus, from the results, the hypothesis cannot be rejected and reach the following conclusions:

1. The use of MONCN digital platform helped the students realize about the application of sustainable development in their own lives, discovering how disruptive technologies could enhance their education and their abilities to cope with their lives in the future.

2. The use of MONCN inspired the students to become citizens of the world and showed them their capability to join the climate change war. As Elena Bonner said: "Just as there are no little people or unimportant lives, there is no insignificant work". Even the insignificant amount of paper saved in a paperless classroom environment, it is an important step to plant in their souls the love for our planet.

3. The feeling of freedom using MONCN, to express what they want and to be liberated from the burden of carrying physical items in their backpacks and the economic savings in educational material, are other seeds that were planted in their souls: an approach to use the minimum resources without sacrificing their excellence in education.

4. The easier connection of the students with their classmates during class discussions and an improvement in team work capabilities made it possible to apply the collaborating learning strategy in class. MONCN made it easier. 
5. When the students expressed that MONCN helped them increase the quality of their education, this confirmed the hypothesis that using a new digital platform will not harm the quality of education given by professors.

6. As Tom Peters said, "Leaders do not create followers, they create more leaders", it is possible to conclude that MONCN is a digital platform that made students happier because it helped them better organize their academic life and realize what can be done in the future using technology. Thus, the new ability using MONCN was an inspiration to transform the students in future leaders, not followers.

7. The questions made in negative form (the last 7 questions) was a strategy to avoid a bias in the answers, and to evaluate if the students were answering and thinking deeply in their responses. This was like a calibration of the survey that successfully resulted in the conclusion that MONCN is a friendly digital platform that improves the effectiveness of teaching an undergraduate course, with the opportunity to plant the seed of ethics and citizenship.

Disruptive Technologies are here to stay. Their speed of appearance will increase throughout the years. Teachers and professors must be prepared to adopt these technologies that will benefit the happiness and life of their students. Indeed, there is a need to improve the technological capacities of the undergraduate professors and prepare them to receive the technological experts of future generations. It will mean a new load of work burden for the professors who need to take courses in new technologies. Change is not easy to accept because it moves us far from our comfortable zone. However, the results of this research is a call to teachers and professors to accept and be involved in the proposed new technologies or platforms like MONCN trying to find ways to make the technology a new tool to convey ethics, values and inspiration to the students who are eager to find models to become better citizens of the world.

\section{Analysis of the Open Question}

As part of the survey, there was one last open question with the freedom to express whatever the student wanted to share regarding his/her experience with MONCN. The question was: "In your own words, would you write about your experience with MONCN in order to be prepared to face the education of future generations with excellence? There were multiple and interesting answers with different points of view; the majority of the comments were in favor of the use of MONCN. However, the students raise important ideas about the limitations of MONCN that could be improved in the future. Three answers were chosen to summarize the students' experience with MONCN as follows:

Student 1: This was my first time with MONCN. At the beginning I felt overwhelmed. I arrived to class with my physical notebook ready to take notes. It was a surprise to see a professor that suddenly began to talk about paperless class, ethics, citizenship of the world and sustainable development. I was upset at the beginning because I thought that I was registered in a financial course, ready to learn about credits, money, etc. I felt disgruntled because the finance issues I was eager to learn about were not mentioned in the first class. At the beginning I thought I was in the wrong classroom, in a computer science course. Even though the first class was a shock for me, suddenly I began to realize the importance of having a professor that offered me more than a simple finance class. My professor gave me technological training, ethics, values, a vision of a geopolitical world within a climate change dilemma. Now I only can express my thanks for opening my mind and my vision about how important it is to develop my technological abilities along with the knowledge in finance and combined them in an excellent way with ethics, citizenship and sustainable development. Thank you professor for working so hard in transforming me in a better person.

Student 2: My experience with MONCN was great. Especially I enjoyed working in class learning from my classmates, feeling integrated and connected with them. Thanks to MONCN everyone uploaded opinions, homework, notes, etc. When the professor began the debate in class, she asked for example, what was the opinion of one specific classmate about a specific financial issue? It was really like magic when the professor said: Let's see what our classmate thinks, and suddenly the opinion my classmate uploaded first in the MONCN platform was displayed on the classroom screen. MONCN indeed helped me learn to work as a team even in class. The professor made us respect the opinion of each one of us, and made us feel important in class. I think that this class and MONCN made me capable to co-work in the future in any type of business environment.

Student 3: The use of MONCN platform as a tool made me feel free. I could upload my homework from any place at any time, letting me combine my social life with my academic one. I remembered my school days when I had to load many things in my school bag: notebooks, pencils, pens, eraser, etc. With MONCN I do not need but my computer in my bag: I felt relieved. However, we had problems with the team debates outside the class. We, as a team, decided to 
use Google Docs for this purpose: it was better and faster. Google offered us a better synchronization speed of several students working simultaneously in the same document. Also, the Discussion Board with my classmates was done through Blackboard. MONCN has some disadvantages in its use: for simultaneous team working and debate. However, the combination of the two available digital platforms let us improve our performance in class. I am the president of our student association in Campus. I offered my team to adopt MONCN for organizing our personal lives and work at the same time in the association. My team accepted my proposal and I am really pleased that even before finishing my finance course, I found an application of MONCN as a leader on Campus. That made me think about the huge possibilities that MONCN could offer me in the future as an executive in any company: I would be able to exercise an effective leadership not only with my knowledge in finance but with my technological abilities to help organize any team work.

From the statement of Student 3, it might be said that the president of the student association on campus followed what Rev. Theodore Hesburgh once said, "You have to have a vision. It's got to be a vision you articulate clearly and forcefully. You can't blow an uncertain trumpet". Indeed, this student could lead others with the use of MONCN in the organization of the activities of the association because it had a clear vision of what this technology could do for them.

Thus, MONCN resulted in an effective digital tool that could be improved according to the comments of the complete student sample, in spite of having the possibility to help in the effective transference of knowledge, team work, freedom in the academic environment, and the possibility to plant the seeds of leadership, ethics and the concept of citizen of the world.

\section{CONCLUSIONS AND RECOMMENDATIONS}

As Aristotle once said, "Pleasure in the job puts perfection in the work", MONCN offers that ingredient of pleasure in the academic job, for professors and students as well. Professors find pleasure in investing time with MONCN and teaching it to the students because this friendly paperless digital platform help them to have an easier way to organize their responsibilities and their lives as well, giving them satisfaction which becomes perfection in their daily work. This outcome sends out a sensation of "accomplished mission" in the difficult but important role of an educator. As the author of this research, it is significant for more professors to participate possibly in replicating the use of MONCN in any campus environment of the world because that could be a great practice and a new beginning in broader academic settings.

After the use of MONCN as a paperless technological platform it was shown that T.H. White was right when he said: "Learning is the only thing which the mind can never exhaust... never fear...and never dream of regretting" (p.2). And for me as a professor, I can just express that if the time invested in learning and using the MONCN platform resulted in having happier, well prepared and ethical students in class, eager to learn and become leaders for others, it was worthy to invest my time using MONCN if it helped me fulfill my mission as a professor easier. 


\section{AUTHOR BIOGRAPHY}

Flory Dieck-Assad, Ph.D. in Finance from Tulane University, USA. Author of "Financial Institutions" by McGrawHill in 2003, and second edition in 2014. With over 250 publications in refereed journals and magazines of national and international scope; member of the National System of Researchers since December 2005 to date; "Texas A \& M University Press" published in 2005 her second book "Energy and Sustainable Development in Mexico", honored with the Romulo Garza Award 2007 with its second printing in 2008. Awarded with the Prize for Teaching \& Research 2007, 2010 and 2014; 2013 National Ethics Award; the 2015 Distinguished Professor of the Institute of Chartered Accountants of the State of Nuevo Leon, Mexico, the 2015 National Energy Prize, and the 2017 Outstanding Research and Educator Woman. Tenured professor at Tecnologico de Monterrey. Tecnológico de Monterrey Mexico. E-mails: fdieck@itesm.mx; fdieck@tec.mx

\section{REFERENCES}

Couturier, S., \& Mas, J. (2009). ¿Qué tan confiable es una tasa de deforestación? ¿Cómo evaluar nuestros mapas con rigor estadístico? Investigación Ambiental UNAM, 1(2), 117-135.

Dieck-Assad, F. (2018). Teaching undergraduate finance via a digital literacy platform. Chapter 13 of the book Promoting Global Competencies Through Media Literacy, DOI: 10.4018/978-1-5225-3082-4.ch013; First Edition, pp. 193-215; IGI Global, Disseminator of Knowledge, U.S.A.

Greenpeace (2018). La deforestación y sus causas. Retrieved February 6, 2018 from $\mathrm{http} / /$ www.greenpeace.org/mexico/es/Campanas/Bosques/La-deforestacion-y-sus-causas/

NTN24.com (2013). El mandatario ecuatoriano, Rafael Correa, plantea realizar una consulta popular para que los diarios ecuatorianos sean exclusivamente digitales para evitar la tala de árboles que requiere la fabricación de papel. Retrieved January 17, 2018 from http:/www.ntn24.com/, https://www.youtube.com/watch?v=Cl1Q-qLBwq0

Once Noticias (2013). Ventajas y desventajas del uso de la tecnología en niños. Retrieved January 4, 2018 from www.oncenoticias.tv, https://youtu.be/gXDgyY1RVqY

OneNote (2018). Bloc de notas de clase de OneNote. Retrieved January 10, 2018 from https://www.onenote.com/classnotebook

OneNote Team (2014a). Introducing OneNote Class Notebooks - a flexible digital framework for teaching and learning. Retrieved December 14, 2017 from https://blogs.office.com/2014/10/07/introducing-onenote-class-notebooks-flexibledigital-framework-teaching-learning/

OneNote Team (2014b). OneNote Class Notebook Creator updated with top educator requests and new language support. Retrieved December 14, 2017 from https://blogs.office.com/2014/12/09/onenote-class-notebook-creator-updated-topeducator-requests-new-language-support/ 